\title{
HIGH GLUCOSE MEDIATES PROOXIDANT AND ANTIOXIDANT ENZYME ACTIVITIES IN CORONARY ENDOTHELIAL CELLS
}

Ulvi Bayraktutan* DVM, PhD; Pamela Weidig, BSc; Dorothy McMaster, PhD; Sibel Ülker, MD

Department of Medicine, Institute of Clinical Science Block B, Queen`s University Belfast, Belfast, United Kingdom

Short title: Hyperglycaemia regulates antioxidant enzyme activity

\author{
*Address for correspondence \\ Dr. Ulvi Bayraktutan \\ Department of Medicine, \\ Institute of Clinical Science Block B \\ Queen`s University Belfast \\ Grosvenor Road \\ Belfast BT12 6BJ \\ United Kingdom \\ Tel: $\quad$ +442890263178 \\ Fax: $\quad$ +442890329899 \\ E-mail: u.bayraktutan@qub.ac.uk
}




\begin{abstract}
Objective: Excess levels of free radicals such as nitric oxide (NO) and superoxide anion $\left(\mathrm{O}_{2}{ }^{-}\right)$ are associated with the pathogenesis of endothelial cell dysfunction in diabetes mellitus. This study was designed to investigate the underlying causes of oxidative stress in coronary microvascular endothelial cells (CMEC) exposed to hyperglycaemia.
\end{abstract}

Methods: CMEC were cultured under normal ( $5.5 \mathrm{mmol} / \mathrm{L})$ or high glucose $(22 \mathrm{mmol} / \mathrm{L})$ concentrations for 7 days. The activity and expression (protein level) of eNOS, iNOS, NAD(P)H oxidase and antioxidant enzymes, namely, superoxide dismutase (SOD), catalase and glutahione peroxidase (GPx) were investigated by specific activity assays and Western analyses, respectively while the effects of hyperglycaemia on nitrite and $\mathrm{O}_{2}{ }^{-}$generation were investigated by Griess reaction and cytochrome $C$ reduction assay, respectively.

Results: Hyperglycaemia did not alter eNOS or iNOS protein expressions and overall nitrite generation, an index of NO production. However, it significantly reduced the levels of intracellular antioxidant glutathione by $50 \%(\mathrm{p}<0.05)$ and increased the protein expressions and/or activities of p22-phox, a membrane-bound component of pro-oxidant NAD(P)H oxidase and antioxidant enzymes $(\mathrm{p}<0.05)$. Free radical-scavengers, namely, Tiron and MPG $(0.1-1$ $\mu \mathrm{mol} / \mathrm{L}$ ) reduced hyperglycaemia-induced antioxidant enzyme activity and increased glutathione and nitrite generation to the levels observed in CMEC cultured in normoglycaemic medium $(\mathrm{p}<0.01)$. The differences in enzyme activity and expressions were independent of the increased osmolarity generated by high glucose levels as investigated by using equimolar concentrations of mannitol in parallel experiments.

Conclusions: These results suggest that hyperglycaemia-induced oxidative stress may arise in CMEC as a result of enhanced prooxidant enzyme activity and diminished generation of 
antioxidant glutathione. By increasing the antioxidant enzyme capacity CMEC may protect themselves against free radical-induced cell damage in diabetic conditions. 


\section{Introduction}

Nitric oxide (NO) is generated from amino acid L-arginine by a class of enzymes termed as NO synthases (NOSs) which include two constitutively expressed isoforms, namely, endothelial NOS (eNOS) and neuronal NOS (nNOS) and an inducible isoform (iNOS) [1, 2]. NO, generated within healthy endothelium by eNOS, plays pivotal roles in the maintenance of vascular tone [3] and in the inhibition of leukocyte adhesion [4] and vascular smooth muscle cell (VSMC) proliferation [5]. The functions and/or integrity of endothelium change in several pathological conditions including diabetes mellitus leading to a phenomenon called "endothelial dysfunction", a hallmark of diabetic vascular complications which is characterised by impaired endothelial cell function and enhanced anti-haemostatic properties [6]. Current data as to the pathogenesis of diabetic endothelial cell dysfunction are extremely diverse in that several mechanisms have so far been proposed to account for this phenomenon. These include inefficient utilisation of substrate L-arginine by NOS for NO synthesis [7], an abnormal NOS activity due to inadequate presence of co-factor tetrahydrobiopterin $\left(\mathrm{H}_{4} \mathrm{~B}\right)$ [8], concurrent release of endothelium-derived constricting factor arising from the cyclooxygenase pathway [9] and NO quenching by advanced glycation end-products (AGEs) [10].

Despite a lack of consensus on the expression and activity of eNOS and therefore generation of NO in diabetic conditions, an overwhelming body of evidence has in recent years indicated that reactive oxygen species (ROS) are released at greater levels in diabetic animals and cells cultured under high glucose conditions $[11,12]$. ROS are, in part, also generated as a direct consequence of constant and prolonged exposure of cells to hyperglycaemia that leads to nonenzymatic glycation of plasma proteins [13]. The glycated products undergo further spontaneous reactions to produce free radicals including superoxide anion $\left(\mathrm{O}_{2}^{-}\right)$, the foundation radical [14]. 
$\mathrm{O}_{2}{ }^{-}$is also formed through the reduction of molecular oxygen by several enzymes such as cyclooxygenase, xanthine oxidase, mitochondrial NADH dehydrogenase, NOSs and NAD(P)H oxidase $[15,16]$. Amongst these enzymes $\mathrm{NAD}(\mathrm{P}) \mathrm{H}$ oxidase has attracted much of the attention in recent years and has been characterised in coronary microvascular endothelial cells (CMEC) as the main source of ROS [17]. It has also been associated with oxidative stress-mediated endothelial dysfunction in the central retinas of type II diabetic rats [18]. NAD(P)H oxidase, consists of a membrane-bound cytochrome $\mathrm{b}_{558}$ that in turn consists of p22-phox and gp91-phox, and several cytosolic subunits, namely, p47-phox, p67-phox, p40-phox and small GTP-binding protein rac [19]. The importance of p22-phox subunit for the activity and stability of the enzyme as a whole has been further emphasised by a recent study in that polymorphism of the p22-phox gene has been linked to initiation and progression of atherosclerotic disease [20].

Under physiological conditions $\mathrm{O}_{2}{ }^{-}$is converted to hydrogen peroxide $\left(\mathrm{H}_{2} \mathrm{O}_{2}\right)$, another ROS, by superoxide dismutases (SODs), namely CuZn-containing (CuZn-SOD) or Mn-containing isoform (Mn-SOD) (21). Once generated, $\mathrm{H}_{2} \mathrm{O}_{2}$ is metabolised to $\mathrm{H}_{2} \mathrm{O}$ by enzymatic activities of catalase and glutathione peroxidase (GPx) [21]. However, in the absence of adequate levels of SODs or intracellular antioxidants such as glutathione [22], $\mathrm{O}_{2}{ }^{-}$rapidly scavenges $\mathrm{NO}$ within the vascular wall to reduce its biological half-life and causes contraction of vascular smooth muscle [23, 24]. Indeed, diminished levels of glutathione have been reported in aortic endothelial cells from diabetic rabbits [25] but not in human umbilical vein endothelial cells cultured in 20 $\mathrm{mmol} / \mathrm{L}$ glucose for 14 days [26]. It is noteworthy in this context that hyperglycaemia may lead to glycosylation of SOD enzymes thereby rendering them inactive and consequently elevating $\mathrm{O}_{2}{ }^{-}$levels [27]. In support of this hypothesis, a recent study has shown that pretreatment with SOD enhances basal and agonist-stimulated endothelium-dependent vascular relaxant responses 
in diabetic rat aorta therefore suggesting an ample presence of $\mathrm{O}_{2}{ }^{-}$in diabetic tissues [28]. It is possible that pathologies in the regulation of catalase and $\mathrm{GPx}, \mathrm{H}_{2} \mathrm{O}_{2}$-scavenging enzymes, may further complicate the oxidative stress status in diabetes and indeed account for its aetiology.

Hence, the current study was designed to investigate the underlying causes of coronary endothelial cell oxidative stress in hyperglycaemic conditions with reference to: 1- availability of intracellular antioxidant glutathione and nitrite, a stable end-product of NO; 2- expression and/or activity of enzymes that may be involved in the regulation of cellular oxidative stress i.e. eNOS, iNOS, SODs, GPx and catalase, NAD(P)H oxidase.

\section{Materials and Methods}

\section{Isolation and Characterisation of CMEC}

The hearts were mounted and perfused retrogradely on a constant-flow Langendorff system with $0.04 \%$ collagenase. The ventricles were then chopped and collagenase digestion was quenched by the addition of bovine serum albumin to the perfusate. CMEC were obtained by sedimentation of myocytes and incubated in $0.01 \%$ trypsin at $37^{\circ} \mathrm{C}$ for the prevention of nonendothelial cell attachment. Cells were then activated by washing in calcium and suspended in Medium 199 (Gibco-BRL) supplemented with 10\% foetal calf serum, 10\% newborn calf serum, benzylpenicillin $250 \mathrm{U} / \mathrm{ml}$, streptomycin $250 \mu \mathrm{g} / \mathrm{ml}$, amphotericin B $12.5 \mu \mathrm{g} / \mathrm{ml}$ and gentamycin $50 \mu \mathrm{g} / \mathrm{ml}$. Cell suspensions were plated and incubated at $37^{\circ} \mathrm{C}$ under $5 \% \mathrm{CO}_{2}$. After $1 \mathrm{~h}$ incubation, unattached cells were washed off with saline and remaining cells were cultured to confluence.

For the different experiments, CMEC were cultured for 7 days in the growth medium containing either $5.5 \mathrm{mmol} / \mathrm{L}$ (normal) or $22 \mathrm{mmol} / \mathrm{L}$ (high) D-glucose. When there was a statistically significant difference between $5.5 \mathrm{mmol} / \mathrm{L}$ and $22 \mathrm{mmol} / \mathrm{L} \mathrm{D}$-glucose, CMEC were 
also cultured in the presence of $5.5 \mathrm{mmol} / \mathrm{L} \mathrm{D}$-glucose $+16.5 \mathrm{mmol} / \mathrm{L} \mathrm{L}$-glucose and $5.5 \mathrm{mmol} / \mathrm{L}$ D-glucose $+16.6 \mathrm{mmol} / \mathrm{L}$ mannitol to investigate the involvement of extracellular glycation and increased osmolarity, respectively in the differences. Growth medium was changed on a daily basis and all experiments were performed on CMEC up to and including passage number 5 . Cultured CMEC were characterised by their typical "cobblestone" morphology and and their ability to form capillary-like tubes on the Matrigel [29].

\section{Western Blotting}

Total cellular proteins were isolated by lysis of CMEC with a boiling solution containing $1 \%$ SDS, $10 \mathrm{mmol} / \mathrm{L}$ Tris $\mathrm{pH}$ 7.4. Equal amounts of protein were run on 10\% SDS-polyacrylamide gels and transferred onto nitrocellulose membranes. The membranes were then incubated overnight with either monoclonal (for eNOS, iNOS and p22-phox antibodies from Transduction Labs.) or polyclonal primary antibodies raised against rat $\mathrm{Cu} / \mathrm{Zn}-\mathrm{SOD}$, rat $\mathrm{Mn}-\mathrm{SOD}$ (Calbiochem) or bovine catalase (Chemicon). Horseradish peroxidase-linked secondary antibodies were then used and the bands were detected by use of a chemiluminescence agent (Amersham Pharmacia). Blots were assessed by densitometry of bands with subtraction of the background counts measured outside loaded lanes. Since, a species-specific antibody for GPx protein could not be obtained, Western analyses for this protein were not performed.

\section{Nitrite Detection}

Nitrite levels were measured by Griess reaction as an index of NO generation following conversion of nitrate to nitrite by nitrate dehydrogenase [30]. An aliquot of the cellular homogenate was mixed with an equal volume of Griess reagent (sulfanilamide 1\% w/v, naphthylethylenediamine dihydrochloride $0.1 \% \mathrm{w} / \mathrm{v}$ and orthophosphoric acid $2.5 \% \mathrm{v} / \mathrm{v}$ ) and incubated at room temperature for $10 \mathrm{~min}$ prior to measurement of absorbances at $540 \mathrm{~nm}$. The 
amount of nitrite formed was compared to those of known concentrations of sodium nitrite and normalised to the protein content of the respective flask.

\section{Superoxide anion $\left(\mathrm{O}_{2}^{-}\right)$Production}

$\mathrm{O}_{2}{ }^{-}$was measured by cytochrome $C$ reduction assay. Briefly, CMEC grown under

normoglycaemic or hyperglycaemic conditions at the density of $5 \times 10^{6}$ cells/ml were incubated with $50 \mu \mathrm{mol} / \mathrm{L}$ cytochrome $C$ for $30 \mathrm{~min}$ at $37^{\circ} \mathrm{C}$ in Hepes buffer. Absorbances were recorded using a Cobas-Fara centrifugal analyser at $550 \mathrm{~nm}$ with 90 seconds intervals for $12 \mathrm{~min}$.

Production of $\mathrm{O}_{2}^{-}$was calculated as previously described and results were expressed as pmoles $\mathrm{O}_{2}^{-}$per $10^{6}$ cells [31].

\section{SOD Assay}

SOD activity was also measured by a reaction dependent upon the inhibition of cytochrome $C$ by endogenous SOD in cellular homogenates using a Cobas Fara centrifugal analyser. The $\mathrm{O}_{2}{ }^{-}$, required for reduction, was generated by a reaction of xanthine-xanthine oxidase (XO). One unit of XO activity was defined by the amount of homogenate required to inhibit, by $50 \%$, the rate of cytochrome $C$ reduction. For assay of total SOD activity, $0.1 \mathrm{mmol} / \mathrm{L}$ xanthine was dissolved in $50 \mathrm{mmol} / \mathrm{L} \mathrm{NaCO}_{3}$ buffer. A dilute stock solution was added to a $10 \mu \mathrm{mol} / \mathrm{L}$ solution of cytochrome $C, 50 \mu \mathrm{mol} / \mathrm{L}$ xanthine, $0.1 \mathrm{mmol} / \mathrm{L}$ EDTA and $50 \mathrm{mmol} / \mathrm{L}$ sodium carbonate to produce a change in absorbance of $0.0250 / \mathrm{min}$ at $550 \mathrm{~nm}$ at $\mathrm{pH} 10$. This was followed by the measurement of Mn-SOD activity, which is resistant to incubation at room temperature with 3 mmol/L potassium cyanide (BDH Chemicals Ltd) for 45 minutes. For Mn-SOD activity the protocol was identical except that carbonate buffer was replaced with $50 \mathrm{mmol} / \mathrm{L}$ potassium phosphate and $\mathrm{pH}$ adjusted to 7.8. CuZn-SOD activity was subsequently calculated by the subtraction of Mn-SOD activity from total SOD activity. 


\section{Catalase Assay}

The activity of catalase was determined by a photometric method where the activity was determined by monitoring the decomposition of $\mathrm{H}_{2} \mathrm{O}_{2}$ at $240 \mathrm{~nm}$ in the presence of methanol which produces formaldehyde which in turn reacts with Purpald (4-amino-3-hydazino-5-

mercapto-1,2,4-triazole) and potassium periodate to produce a chromophore. Quantification was performed in comparison to the results obtained with catalase and formaldehyde standards.

\section{GPx Assay}

The activity of GPx was determined in cellular homogenates using a method developed by McMaster et al [32]. Briefly, a fresh solution containing $0.3 \mathrm{U} / \mathrm{ml}$ glutathione reductase, 1.25 $\mathrm{mmol} / \mathrm{L}$ reduced glutathione and $0.19 \mathrm{mmol} / \mathrm{L} \mathrm{NADPH}$ in $50 \mathrm{mmol} / \mathrm{L}$ potassium buffer $(\mathrm{pH} 7.4)$ was prepared. Homogenates of $100 \mu \mathrm{g}$ total protein were added to this solution and incubated for 3 minutes prior to addition of $12 \mathrm{mmol} / \mathrm{L} \mathrm{t}$-butylhydroperoxide to commence the reaction. Absorbances were read at $340 \mathrm{~nm}$ for $4 \mathrm{~min}$. Activities were calculated as nmole glutathione/mg protein/min.

\section{Glutathione Assay}

A modified technique of Griffith was used to measure both reduced (GSH) and oxidized (GSSG) glutathione levels using a Cobas Fara centrifugal analyser [33]. To detect GSSG, samples were treated with 2-vinylpyridine that effectively inhibited GSH. Due to low abundance of GSSG, CMEC were pooled from at least eight T75 flasks prior to analysis.

\section{Cell Viability Assay}

A small aliquot of CMEC grown under different conditions was incubated in $0.1 \%$ trypan blue for 3-4 min and viewed under a light microscope. Dead cells were permeable to trypan blue and thus become coloured. By counting 100 cells, the percentage of viable cells was calculated. 


\section{Statistical Analysis}

Results were presented as mean \pm SEM. Statistical analysis was performed by a Student's $t$ test and $\mathrm{P}<0.05$ was considered statistically significant.

\section{Results}

\section{Effects of hyperglycaemia on eNOS, iNOS, p22-phox and antioxidant enzyme protein} expressions

The treatment of CMEC with high glucose concentrations $(22 \mathrm{mmol} / \mathrm{L}$ ) failed to alter eNOS and iNOS protein expressions but significantly increased p22-phox, CuZn-SOD, Mn-SOD and catalase protein levels ( $P<0.05$ for each protein) as assessed by Western analyses (Fig. 1). The differences in protein expression were independent of both extracellular glycation and the increase in osmolarity as equimolar concentrations of L-glucose and mannitol did not alter the level of protein expressions, respectively (data not shown).

\section{Effects of hyperglycaemia on nitrite and $\mathrm{O}_{2}{ }^{-}$generation and antioxidant enzyme activities}

In accordance with the observed increases in protein expression, hyperglycaemia enhanced the $\mathrm{O}_{2}{ }^{-}$generation $(P<0.05)$ and activities of CuZn-SOD, Mn-SOD, catalase and GPx $(P<0.05$ for each enzyme). However, it failed to change the levels of nitrite production compared to CMEC cultured under normoglycaemic conditions $(P>0.05)$. Equimolar concentrations of L-glucose or mannitol did not have any impact on enzyme activities or nitrite generation as compared to cells grown under normoglycaemic conditions $(P>0.05)$ (Table 1$)$.

Effects of free radical scavengers on nitrite and $\mathrm{O}_{2}^{-}$generation and antioxidant enzyme activities

Concurrent incubation of CMEC with $22 \mathrm{mmol} / \mathrm{L}$ glucose plus one of the free radical scavengers, namely, mercaptopropionylglycine (MPG, $0.1-1 \mu \mathrm{mol} / \mathrm{L})$ or Tiron $(0.1-1 \mu \mathrm{mol} / \mathrm{L})$ 
reduced antioxidant enzyme activity to the levels observed in CMEC cultured with $5.5 \mathrm{mmol} / \mathrm{L}$ glucose $(P<0.05)$. These treatments significantly increased nitrite generation and diminished $\mathrm{O}_{2}^{-}$ availability in a dose-dependent manner $(P<0.05)$. These alterations were not observed in CMEC cultured in equimolar mannitol (Table 2).

\section{Effects of hyperglycaemia on intracellular glutathione levels}

Exposure of CMEC to high glucose levels $(22 \mathrm{mmol} / \mathrm{L})$ resulted in a significant decrease in both GSH and GSSG levels compared to CMEC grown in equimolar mannitol or normoglycaemic conditions $(P<0.01)$. However, treatment of $\mathrm{CMEC}$ with $1 \mu \mathrm{mol} / \mathrm{L}$ concentration of either Tiron or MPG significantly increased glutathione levels $(P<0.01)$ (Table 3).

\section{Effects of hyperglycaemia on CMEC viability}

There were no significant differences in CMEC viability between cells cultured in different concentrations of glucose as assessed by trypan blue exclusion assay. Approximately $85 \pm 8 \%$ vs $79 \pm 5 \%$ of normoglycaemic and hyperglycaemic cells were viable, respectively $(P>0.05)$.

\section{Discussion}

The endothelium synthesises and/or releases a wide variety of substances including angiotensin II, prostacyclin and NO in response several chemical, physical and humoral stimuli [6]. Because of their ability to release several vasoactive agents and their strategic localisation, as they constitute the first port of call for any exogenous or endogenous insult, it was critical to study the response of endothelial cells in relation to pathogenesis of hyperglycaemia-induced oxidative stress. NO, the most potent endothelium-derived vasodilator, plays pivotal roles in the maintenance of normal vascular tone, in the modulation of inflammatory and immune responses and in the inhibition of low-density lipoprotein oxidation, VSMC proliferation and leukocyte 
migration and adhesion [3 - 5]. Three isoforms of NOSs have been characterised to date, all of which are the products of separate genes and are divided into two classes with respect to their requirement of $\mathrm{Ca}^{2+}$ for their enzymatic activity [34]. The isoforms originally found in endothelial cells (eNOS) and in neuronal cells (nNOS) are constitutively expressed and require $\mathrm{Ca}^{2+}$ for their activity while an inducible isoform (iNOS) is solely expressed in response to several stimuli including cytokines and does not require $\mathrm{Ca}^{2+}$ for its enzymatic activity [1, 2]. Although eNOS is constitutively expressed, many pathological stimuli like genetic hypertension [35] regulate its expression. However, the activity and expression of eNOS therefore eNOSmediated generation of NO remain rather controversial under many other pathological states such as diabetes mellitus, a metabolic disorder characterised by hyperglycaemia. Indeed, both enhanced and diminished expression of eNOS and production of NO has so far been reported in patients with diabetes mellitus, in animal models of diabetes and in cells cultured under high glucose conditions $[7,11,12,36,37]$.

In contrast to eNOS, iNOS produces greater amounts of NO that may lead to cell damage, inflammation, atherosclerosis and myocardial dysfunction in diabetic conditions [38, 39]. Indeed, the inhibitors of iNOS namely, aminoguanidine and NOX-101 have been shown to be beneficial in preventing diabetic vascular permeability and endothelial dysfunction thereby indicating the significance of iNOS-mediated generation of NO in disease settings [40, 41]. In the current study nitrite production, a stable end-product of NO, has been shown to be similar in CMEC cultured with normal (5.5 mmol/L) and high (22 mmol/L) glucose concentrations for 7 days thus suggesting similar rate of expression for both potential NO-generating enzymes. In order to substantiate this hypothesis, the levels of eNOS and iNOS protein expressions were investigated. Our findings have shown a similar degree of protein expressions for both enzymes and similar 
rates of cell viability in CMEC grown under aforementioned conditions. Taken together these data suggest that alteration in $\mathrm{NO}$ levels cannot account, at least during the duration of our experiments, for the vascular changes and endothelial cell dysfunction.

The amount of functional NO is also determined by the availability of free radicals in particular $\mathrm{O}_{2}{ }^{-}$which rapidly scavenges $\mathrm{NO}$ to reduce its biological half-life, causes contraction of VSMC and diminishes $\mathrm{Ca}^{2+}$ signals $[23,24]$. At lower concentrations, free radicals modulate an endothelium adaptation to ensure endothelial vasomotion control while at higher concentrations they affect several intracellular pathways such as kinases, phosphatases and transcription factors such as NFKB and AP-1. The activation of these pathways may subsequently lead to endothelial barrier disruption, cell lysis potentially by producing other potent free radicals like the hydroxyl radical catalysed by iron during the Fenton reaction [42].

$\mathrm{NAD}(\mathrm{P}) \mathrm{H}$ oxidase has recently been shown as the main source of free radicals in rat CMEC where the contributions of other $\mathrm{O}_{2}{ }^{-}$-generating enzymes including cyclooxygenase, xanthine oxidase and NOSs to oxidative stress were found to be negligible using the selective inhibitors of these enzymes [17]. Hence, in the present study the levels of $\mathrm{O}_{2}{ }^{-}$and the expression of p22-phox protein, a membrane-bound component of $\mathrm{NAD}(\mathrm{P}) \mathrm{H}$ oxidase that plays a central role in the activity and stability of the whole enzyme complex [19], were investigated in CMEC cultured in normoglycaemic and hyperglycaemic medium. The results have revealed a marked increase in both $\mathrm{O}_{2}{ }^{-}$production and expression of p22-phox protein in CMEC cultured under high (22 $\mathrm{mmol} / \mathrm{L}$ ) glucose concentrations. In support of the current data the previous studies have shown $\mathrm{NAD}(\mathrm{P}) \mathrm{H}$ oxidase-mediated increases in $\mathrm{O}_{2}^{-}$levels in both diabetic rat aorta and endothelial cells grown under hyperglycaemic conditions $[11,12]$. It is noteworthy that ROS may also be generated as a direct consequence of constant and prolonged in vivo or in vitro exposure of cells 
to hyperglycaemia $[13,14]$. This process leads to protein kinase $\mathrm{C}$ activation and non-enzymatic glycation of plasma proteins which then undergo further spontaneous reactions resulting in the excess production of ROS like $\mathrm{O}_{2}^{-}$. Many other biochemical pathways associated with hyperglycaemia e.g. polyol pathway and eicosanoid synthesis may also increase the production of $\mathrm{O}_{2}^{-}[13,14]$

In the present study, the relationship between free radicals and coronary endothelial cell dysfunction was further investigated by use of one of the two structurally distinct $\mathrm{O}_{2}^{-}$-scavengers namely, Tiron and MPG. Both agents have been shown to be beneficial in ameliorating endothelial cell oxidative stress in that they significantly reduced the elevated levels of $\mathrm{O}_{2}{ }^{-}$and increased the levels of nitrite in CMEC cultured in high $(22 \mathrm{mmol} / \mathrm{L})$ glucose concentrations in a dose-dependent manner. This finding was in good agreement with a previous study showing that free radical scavengers and antioxidant agents like probucol alleviate endothelial cell dysfunction in the abdominal aorta of diabetic rats [43]. These results may suggest a potential role for ROSscavengers in eNOS gene regulation in addition to their well-known free radical-scavenging effects.

The rise in glucose concentration has been associated with a concurrent marked decrease in both oxidised (GSSG) and reduced (GSH) glutathione levels in CMEC that was reversed by the addition of either Tiron $(1 \mu \mathrm{mol} / \mathrm{L})$ or MPG $(1 \mu \mathrm{mol} / \mathrm{L})$. Glutathione is a key aqueous phase antioxidant in cells and its depletion has been previously reported in retinal pericytes [22] and endothelial cells [25] cultured in high glucose concentrations where increases in malondialdehyde as well as CuZn-SOD and Mn-SOD mRNA levels were also reported. Although the underlying mechanisms of glutathione depletion remain to be determined in full, decreases have been reported in the gene expression and activity of $\gamma$-glutamyl cysteine 
synthetase ( $\gamma$-GCS), the rate-limiting enzyme in glutathione synthesis, with high glucose concentrations [44]. Moreover, glucose-derived modification of this enzyme has been implicated in the predisposition of erythrocytes to oxidative stress thereby implying the possibility that a similar mechanism could also be responsible for decreased glutathione in CMEC which would predispose them to oxidant-mediated damage [45]. However, it is also possible that free radicals rather than glucose per se may account for inactivation of $\gamma$-GCS.

Hyperglycaemic-oxidative stress may be further exacerbated by the inactivation or deficiency of SODs that metabolise $\mathrm{O}_{2}{ }^{-}$to $\mathrm{H}_{2} \mathrm{O}_{2}$ (21), another ROS that causes irreversible endothelial damage linked with diminished $\mathrm{NO}$ and is detoxified to $\mathrm{H}_{2} \mathrm{O}$ by either catalase or GPx [21]. If $\mathrm{H}_{2} \mathrm{O}_{2}$ is not dismutated sufficiently, then excess $\mathrm{H}_{2} \mathrm{O}_{2}$ is converted to toxic hydroxyl radicals through the Fenton reaction [42]. Thus, investigating the high glucose-induced changes in antioxidant enzyme expression and activities was an appropriate way to elucidate hyperglycaemia-related oxidative injuries in vitro. We have found in the current study that hyperglycaemia elicits significant increases in Mn-SOD, CuZn-SOD, GPx and catalase protein expression and/or activity in rat CMEC. The increases in antioxidant enzyme activities were in keeping with their well-known induction in response to oxidative stress and have also been previously reported in human endothelial cells [46] and in patients with type II diabetes mellitus [47]. In contrast to these reports, a recent study has shown that gene transfer of eNOS but not CuZn-SOD failed to improve the endothelium-dependent vascular relaxation in carotid arteries from diabetic rabbits [48]. This may be explained by either inability of CuZn-SOD to penetrate to vascular smooth muscle layer or by hyperglycaemia-induced glycosylation and therefore inactivation of SOD enzymes [27]. In support of these hypothesis, a recent study has shown that pretreatment with cell-permeable SOD enhances basal and agonist-stimulated endothelium- 
dependent vascular relaxant responses in diabetic rat aorta [28]. It therefore appears reasonable to hypothesise that elevated expression and/or activity of antioxidant enzymes is an adaptive response of CMEC to meet the biological demand exerted by hyperglycaemic oxidative stress. Although the current study did not investigate the underlying causes of the increases in antioxidant gene expression, a recent study has revealed that transcriptional, translational and post-translational regulations as major determinants of local antioxidant enzyme levels in the renal cortex of diabetic rats [49].

In conclusion, the current study has shown that the aetiology of hyperglycaemia-induced oxidative stress in CMEC is multi-factorial. Endothelial cell dysfunction is associated with increased $\mathrm{O}_{2}^{-}$production as opposed to inadequate synthesis of NO thereby suggesting the idea that decreasing $\mathrm{O}_{2}^{-}$levels may have beneficial therapeutic implications. By increasing the antioxidant enzyme capacity, CMEC may equip themselves better protected against free radicalsinduced cell damage in diabetic conditions.

\section{Acknowledgements}

This study was supported by the Royal Society UK grant to Dr Ulvi Bayraktutan.

\section{References}

1 Iyengar R, Stuehr DJ, Marletta MA. Macrophage synthesis of nitrite, nitrate and Nnitrosoamines: precursors and role of the respiratory burst. Proc Natl Aca Sci USA 1987; 84: 6369-6373

2 Hibbs JB, Taintor RR, Vavrin Z. Macrophage cytotoxicity: role of L-arginine deiminase and imino nitrogen oxidation to nitrite. Science 1987; 235: 473-476

3 Lerman A, Burnett JC Jr. Intact and altered endothelium in regulation of vasomotion. Circulation 1992; 86: III12-III19 
4 Kubes P, Suzuki M, Granger DN. NO: an endogenous modulator of leukocyte adhesion. Proc Natl Aca Sci USA 1991; 88: 4651-4655

5 Garg UC, Hassid A. Nitric oxide-generating vasodilators and 8-bromo-cyclic guanosine monophospahte inhibit mitogenesis and proliferation of cultured rat vascular smooth muscle cells. J Clin Invest 1989; 83: 1774-1777

6 Bayraktutan U. Free radicals, diabetes and endothelial dysfunction. Diabet Obes Metabol 2002; 4: 224-238

7 Pieper GM, Peltier BA. Amelioration by L-arginine of a dysfunctional arginine/nitric oxide pathway in diabetic endothelium. J Cardiovasc Pharmacol 1995; 25: 397-403

8 Pieper GM. Acute amelioration of diabetic endothelial dysfunction with a derivative of the nitric oxide synthase cofactor, tetrahydrobiopterin. J Cardiovasc Pharmacol 1997; 29; 8-15

9 Tesfamariam B, Jakubowski JA, Cohen RA. Contraction of diabetic rabbit aorta caused by endothelium-derived $\mathrm{PGH}_{2}-\mathrm{TxA}_{2}$. Am Journal of Physiology 1989; 57: H1327-H1333

10 Bucala R, Tracey KJ, Cerami A. Advanced glycosylation products quench NO and mediate defective endothelium-dependent vasodilatation in experimental diabetes. J Clin Invest 1991; 87: $432-438$

11 Langenstroer P, Pieper GM. Regulation of spontaneous EDRF release in diabetic rat aorta by oxygen free radicals. Am J Physiol 1992; 263: H257-H262

12 Graier WF, Pusch K, Wascher T. Increased superoxide formation in endothelial cells during hyperglycemia. Diabet Res Clin Prac 1999; 45: 153-160

13 Tames FJ, Mackness MI, Arrol S, Laing I, Durrington PN. Non-enzymatic glycation of apolipoprotein B in the sera of diabetic and non-diabetic subjects. Atheroscler 1992; 93: 237 244 
14 Sakari T, Sugioka K, Nakano M. $\mathrm{O}_{2}^{-}$generation and lipid peroxidation during oxidation of a glycated polypeptide, glycated polylysine, in the presence of iron-ADP. Biochim Biophys Acta 1997; 1043: 27-33

15 Xia Y, Dawson VL, Dawson TM, Snyder SH, Zweier JL. NOS generates superoxide and NO in arginine depleted cells leading to peroxynitrite-mediated cellular injury. Proc Natl Aca Sci USA 1994; 93: 6770-6774

16 Matsumoto S, Koshiishi I, Inoguchi T, Nawata H, Utsumi H. Confirmation of superoxide generation via xanthine oxidase in streptozotocin-induced diabetic mice. Free Rad Res 2003;

37: $767-772$

17 Bayraktutan U, Draper N, Lang D, Shah AM. Expression of a functional neutrophil-type NADPH oxidase in cultured rat coronary microvascular endothelial cells. Cardiovasc Res 1998; 38: 256-262

18 Ellis EA, Grant MB, Murray FT, Wachowski MB. Increased NADH oxidase activity in the retina of the BBZ/WOR diabetic rat. Free Rad Biol Med 1998; 24: 111-120

19 Bayraktutan U, Blayney L, Shah AM. Molecular characterisation and localisation of the $\mathrm{NAD}(\mathrm{P}) \mathrm{H}$ oxidase components gp91-phox and p22-phox in endothelial cells, Arterioscler Thromb Vasc Biol 2000; 20: 1903-1911

20 Cahilly C, Ballantyne CM, Lim DS, Gotto A, Marian AC. A variant of p22(phox) involved in generation of reactive oxygen species in the vessel wall, is associated with progression of coronary atherosclerosis. Circ Res 2000; 86: 391-395

21 Yu BP. Cellular defenses against damage from reactive oxygen species. Physiol Rev 1994; 74: $139-162$ 
22 Sharpe PC, Liu WH, Yue KKM, McMaster D, Catherwood MA, McGinty AM, Trimble ER. Glucose-induced oxidative stress in vascular contractile cells. Diabetes 1998; 47: 801-809

23 Graier, Pusch K, Wascher T. Increased superoxide formation in endothelial cells during hyperglycemia. Diabet Res Clin Prac 1999; 45: 153-160

24 Gryglewski RJ, Palmer RM, Moncada S. $\mathrm{O}_{2}{ }^{-}$is involved in the breakdown of NO. Nature 1986; 320: 454-456

25 Tagami S, Kondo T, Yoshida K, Hirokawa J, Ohtsuka Y, Kawakami Y. Effect of insulin on impaired antioxidant activities in aortic endothelial cells from diabetic rabbits. Metabolism 1992; 41: 1053-1058

26 Kashiwagi A, Asahina T, Ikebuchi M et al. Abnormal glutathione metabolism and increased cytotoxicity caused by $\mathrm{H}_{2} \mathrm{O}_{2}$ in human umbilical vein endothelial cells cultured in high glucose medium. Diabetologia 1994; 37: 264-269

27 Arai K, Izuka S, Tada Y, Oikawa K, Taniguchi N. Increase in the glucosylated form of erythrocyte $\mathrm{CuZn}$ superoxide dismutase in diabetes and close association of the nonenzymatic glucosylation with the enzyme activity. Biochim Biophys Acta 1987; 924: 292296

28 Langenstroer P, Pieper GM. Regulation of spontaneous EDRF release in diabetic rat aorta by oxygen free radicals. Am J Physiology 1992; 263: H257-H262

29 Nishida M, Carley WW, Gerritsen ME, Ellingsen O, Kelly RA. Isolation and characterisation of human and rat cardiac microvascular endothelial cells. American J Physiol 1993; 264: H639-H652.

30 Green LC, Wagner DA, Glogowski J, Skipper PL, Wishnok JS, Tannenbaum SR. Analysis of nitrate, nitrite and $\left[{ }^{15} \mathrm{~N}\right]$ nitrate in biological fluids. Anal Biochem 1982; 126: 131-138 
31 Horie S, Kita H. CD11b/CD18 is required for degranulation of human eosinophils induced by human recombinant granulocyte-macrophage colony-stimulating factor and plateletactivating factor. J Immunol 1994; 152: 5457-5467

32 McMaster D, Bell N, Anderson P et al., Automated measurement of two indicators of human selenium status and applicability to population studies. Clin Chem 1990; 36: 211-216

33 Griffith OW. Determination of glutathione and glutathione disulfide using glutathione reductase and 2-vinyl-pyridine. Anal Biochem 1980; 28: 207-212

34 Nathan C, Xie QW. Regulation of biosynthesis NO. J Biol Chem 1994; 269: 13275-13278

35 Bayraktutan U, Yang ZK, Shah AM. Selective dysregulation of nitric oxide synthase type 3 in cardiac myocytes but not coronary microvascular endothelial cells of spontaneously hypertensive rat. Cardiovasc Res 1998; 38: 719-726

36 Cosentino F, Hishikawa K, Katusic ZS, Luscher TF. High glucose increases nitric oxide synthase expression and superoxide anion generation in human aortic endothelial cells. Circulation 1997; 96: 25-28

37 Chakravathy U, Hayes RG, Stitt AW, McAuley E, Archer DB. Constitutive nitric oxide synthase expression in retinal vascular endothelial cells is suppressed by high glucose and advanced glycation end products. Diabetes 1998; 47: 945-952

38 Kuhlencordt PJ, Chen J, Han F, Astern J, Huang PL. Genetic deficiency of inducible nitric oxide synthase reduces atherosclerosis and lowers plasma lipid peroxides in apolipoprotein E-knockout mice. Circulation 2001; 103: 3099-3104

39 Feng Q, Lu X, Jones DL, Shen J, Arnold JM. Increased inducible nitric oxide synthase expression contributes to myocardial dysfunction and higher mortality after infarction in mice. Circulation 2001; 104: 700-704 
40 Corbett JA, Tilton RG, Chang K et al. Aminoguanidine, a novel inhibitor of nitric oxide formation, prevents diabetic vascular dysfunction. Diabetes 1992; 41: 552-556

41 Pieper GM, Dembny K, Siebeneich W. Long-term treatment in vivo with NOX-101, a scavenger of nitric oxide, prevents diabetes-induced endothelial dysfunction. Diabetologia 1998; 41: 1220-1226

42 Kvietys PR, Inauen W, Bacon BR, Grisham MB. Xanthine oxidase-induced injury to endothelium: role of intracellular iron and hydroxyl radical. Am J Physiol 1989; 257: H1640H1646

43 Tesfamariam B, Cohen RA. Free radicals mediate endothelial cell dysfunction caused by elevated glucose. Am J Physiol 1992; 263: H321-H326

44 Powell LA, Nally SM, McMaster D, Catherwood MA, Trimble ER. Restoration of glutathione levels in vascular smooth muscle cells exposed to high glucose conditions. Free Rad Biol Med 2001; 31: 1149-1155

45 Seltzer HS. Blood glutathione levels in mild diabetes before treatment and during sulfonylurea-induced hypoglycemia. Proc Soc Exp Biol Med 1975; 95: 74-76

46 Ceriello A, dello Russo P, Amstad P, Cerutti P. High glucose induces antioxidant enzymes in human endothelial cells in culture. Diabetes 1996; 45: 471-477

47 Aydin A, Orhan H, Sayal A, Ozata M Sahin G, Isimer A. Oxidative stress and nitric oxide related parameters in type II diabtes mellitus: effect of glycemic control. Clin Biochem 2001; 34:65-70

48 Lund DD, Faraci FM, Miller FJ, Heistad DD. Gene transfer of eNOS improves relaxation of carotid arteries from diabetic rabbits. Circulation 2000; 101: 1027-1033 
49 Limaye PV, Raghuram N, Sivakami S. Oxidative stress and gene expression of antioxidant enzymes in the renal cortex of streptozotocin-induced diabetic rats. Mol Cell Biochem 2003;

243: $147-152$ 


\section{Figure Legends}

Fig. 1. (A) Representative Western blots showing the protein expression of endothelial nitric oxide synthase (eNOS), inducible nitric oxide synthase (iNOS), p22-phox, CuZn-SOD, Mn-SOD and catalase in CMEC cultured under normoglycaemic (lanes 1; $5.5 \mathrm{mmol} / \mathrm{L}$ ) and hyperglycaemic (lanes 2; $22 \mathrm{mmol} / \mathrm{L}$ glucose) conditions for 7 days. (B) Histogram showing the fold differences in protein expression observed in CMEC cultured under hyperglycaemic versus normoglycaemic conditions. Data are expressed as mean $\pm \mathrm{SEM}, \mathrm{n}=3, * P<0.05$, normoglycaemic vs hyperglycaemic conditions. 
A

eNOS

iNOS

p22-phox

CuZn-SOD

Mn-SOD

Catalase

1
$140 \mathrm{kDa}$

$130 \mathrm{kDa}$

$22 \mathrm{kDa}$

$16 \mathrm{kDa}$

$25 \mathrm{kDa}$

$65 \mathrm{kDa}$

B

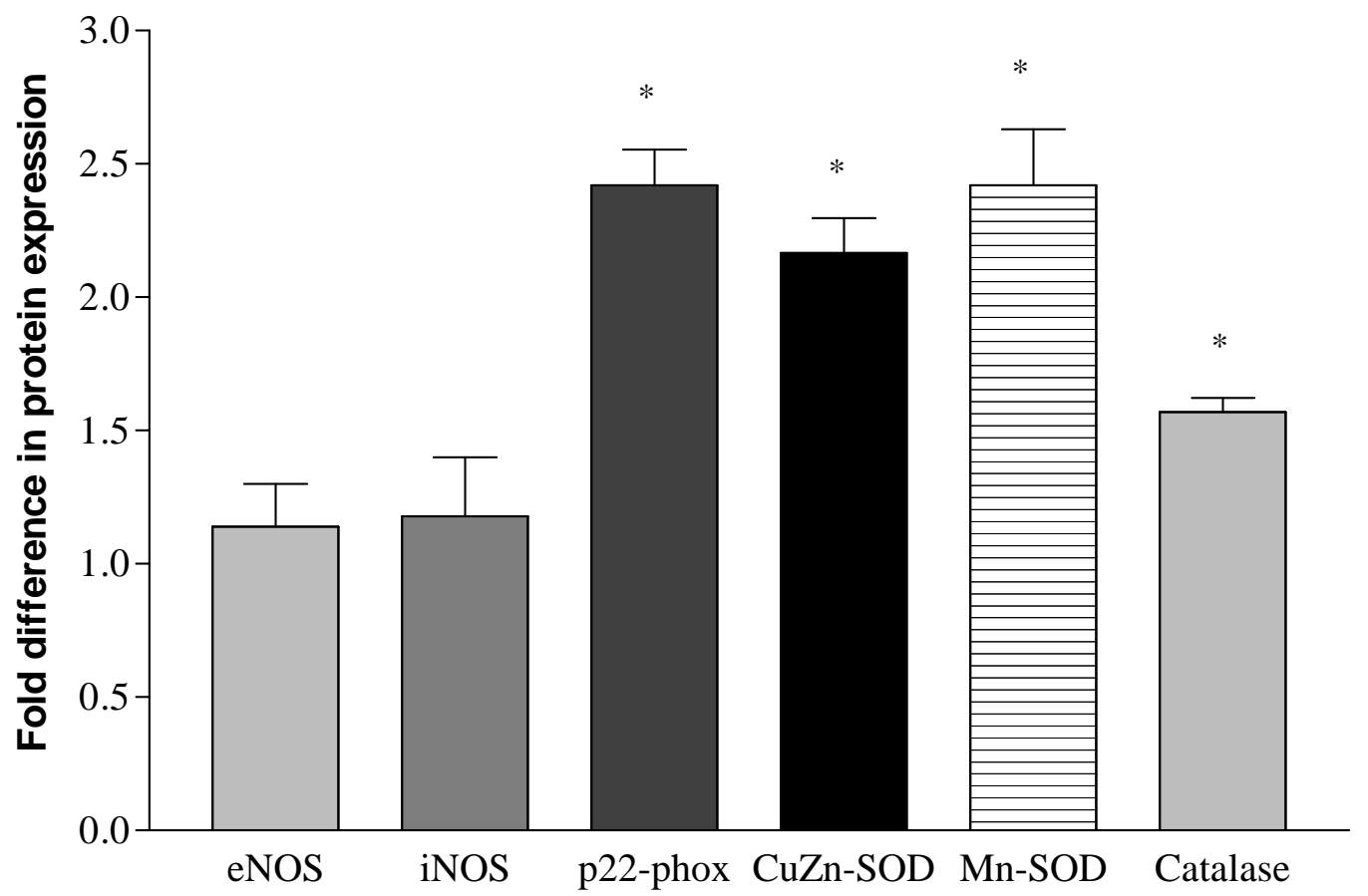


Table 1 Effect of glucose on nitrite and $\mathrm{O}_{2}{ }^{-}$production and antioxidant enzyme activities.

\begin{tabular}{lcccccc}
\hline & Nitrite & $\mathrm{O}_{2}^{-}$levels & CuZn-SOD & Mn-SOD & Catalase & GPx \\
& $(\mathrm{nmol} / \mathrm{mg}$ protein $)$ & $\left(\right.$ pmoles $/ 10^{6}$ cells $)$ & $(\mathrm{mU} / \mathrm{mg}$ protein $)$ & $(\mathrm{mU} / \mathrm{mg}$ protein $)$ & $(\mathrm{U} / \mathrm{mg}$ protein $)$ & $(\mathrm{mU} / \mathrm{mg} \mathrm{protein})$ \\
\hline $\mathrm{NG}$ & $12.13 \pm 0.61$ & $45 \pm 5$ & $630 \pm 110$ & $80 \pm 20$ & $4.12 \pm 0.86$ & $236 \pm 47$ \\
$\mathrm{HG}$ & $13.31 \pm 0.66$ & $98 \pm 11^{*}$ & $960 \pm 130^{*}$ & $170 \pm 40^{*}$ & $7.12 \pm 0.93^{*}$ & $555 \pm 59^{*}$ \\
Control & $12.39 \pm 0.66$ & $42 \pm 6$ & $670 \pm 110$ & $70 \pm 23$ & $3.69 \pm 0.73$ & $246 \pm 41$ \\
\hline
\end{tabular}

NG, $5.5 \mathrm{mmol} / \mathrm{L}$ glucose; HG, $22 \mathrm{mmol} / \mathrm{L}$ glucose; Control, $\mathrm{NG}+16.5 \mathrm{mmol} / \mathrm{L}$ mannitol. The levels of nitrite, $\mathrm{O}_{2}{ }^{-}$and antioxidant enzyme activities in CMEC cultured in NG, HG or Control medium for 7 days were measured as described in the Materials and Methods. Results are expressed as means means \pm s.e.m. from 4 separate experiments. ${ }^{*} P<0.05$ difference compared to NG group. 
Table 2 Effects of free-radical scavengers, Tiron and MPG, on nitrite and $\mathrm{O}_{2}{ }^{-}$levels and antioxidant enzyme activities.

\begin{tabular}{|c|c|c|c|c|c|c|}
\hline & $\begin{array}{c}\text { Nitrite } \\
(\mathrm{nmol} / \mathrm{mg} \text { protein })\end{array}$ & $\begin{array}{c}\mathrm{O}_{2}^{-} \text {levels } \\
\left.\text { (pmoles } / 10^{6} \text { cells }\right)\end{array}$ & $\begin{array}{c}\text { CuZnSOD } \\
\text { (mU/mg protein) }\end{array}$ & $\begin{array}{c}\text { MnSOD } \\
\text { (mU/mg protein) }\end{array}$ & $\begin{array}{c}\text { Catalase } \\
\text { (U/mg protein) }\end{array}$ & $\begin{array}{c}\text { GPX } \\
\text { (mU/mg protein) }\end{array}$ \\
\hline $\mathrm{NG}$ & $12.13 \pm 0.61$ & $45 \pm 5$ & $630 \pm 110$ & $80 \pm 20$ & $4.12 \pm 0.86$ & $236 \pm 47$ \\
\hline $\mathrm{HG}$ & $13.31 \pm 0.66$ & $98 \pm 11^{*}$ & $960 \pm 130^{*}$ & $170 \pm 40^{*}$ & $7.12 \pm 0.93^{*}$ & $555 \pm 59^{*}$ \\
\hline $\mathrm{NG}+1 \mu \mathrm{M} \mathrm{MPG}$ & $13.42 \pm 0.76$ & $38 \pm 7$ & $580 \pm 60$ & $60 \pm 10$ & $4.74 \pm 0.81$ & $216 \pm 31$ \\
\hline $\mathrm{NG}+1 \mu \mathrm{M}$ Tiron & $13.77 \pm 0.81$ & $41 \pm 4$ & $595 \pm 55$ & $60 \pm 12$ & $4.38 \pm 0.60$ & $222 \pm 33$ \\
\hline $\mathrm{HG}+0.1 \mu \mathrm{M}$ MPG & $18.81 \pm 1.01^{* \dagger}$ & $63 \pm 7^{* \dagger}$ & $660 \pm 110$ & $100 \pm 21$ & $4.96 \pm 0.81$ & $261 \pm 42$ \\
\hline $\mathrm{HG}+1 \mu \mathrm{M} \mathrm{MPG}$ & $20.61 \pm 1.21^{* \dagger}$ & $41 \pm 6^{\dagger}$ & $490 \pm 70$ & $60 \pm 9$ & $3.78 \pm 0.69$ & $201 \pm 17$ \\
\hline $\mathrm{HG}+0.1 \mu \mathrm{M}$ Tiron & $18.23 \pm 0.96^{* \dagger}$ & $57 \pm 5^{* \dagger}$ & $715 \pm 105$ & $110 \pm 30$ & $4.77 \pm 0.88$ & $312 \pm 52$ \\
\hline $\mathrm{HG}+1 \mu \mathrm{M}$ Tiron & $20.99 \pm 1.09^{* \dagger}$ & $39 \pm 5^{\dagger}$ & $520 \pm 100$ & $65 \pm 10$ & $4.11 \pm 0.66$ & $223 \pm 38$ \\
\hline
\end{tabular}

$\mathrm{NG}, 5.5 \mathrm{mmol} / \mathrm{L}$ glucose; $\mathrm{HG}, 22 \mathrm{mmol} / \mathrm{L}$ glucose. The levels of nitrite, $\mathrm{O}_{2}{ }^{-}$and antioxidant enzyme activities were measured in CMEC cultured in NG or HG medium for 7 days in the absence and presence of free-radical scavengers, Tiron and MPG. Results were expressed as means \pm s.e.m. from 4 separate experiments. ${ }^{*} P<0.05$ difference compared to NG group, ${ }^{\dagger} P<0.05$ difference compared to HG group. 
Table 3 Effect of glucose and free radical-scavengers, Tiron and MPG on reduced (GSH) and oxidised glutathione (GSSG) levels.

\begin{tabular}{lcc}
\hline & GSSG (nmol/mg protein) & GSH (nmol/mg protein) \\
\hline NG & $0.064 \pm 0.009$ & $2.26 \pm 0.28$ \\
HG & $0.029 \pm 0.004^{*}$ & $1.23 \pm 0.13^{*}$ \\
Control & $0.068 \pm 0.008$ & $2.17 \pm 0.23$ \\
$\mathrm{HG}+1 \mu \mathrm{M}$ Tiron & $0.071 \pm 0.007^{\dagger}$ & $2.47 \pm 0.32^{\dagger}$ \\
$\mathrm{HG}+1 \mu \mathrm{M}$ MPG & $0.073 \pm 0.010^{\dagger}$ & $2.26 \pm 0.21^{\dagger}$
\end{tabular}

NG, $5.5 \mathrm{mmol} / \mathrm{L}$ glucose; HG, $22 \mathrm{mmol} / \mathrm{L}$ glucose. Results were expressed as means \pm s.e.m. from 4 separate experiments. ${ }^{*} P<0.05$ difference compared to NG group, ${ }^{\dagger} P<0.05$ difference compared to $\mathrm{HG}$ group. 